\title{
Adjudicator 2
}

National Cancer Institute

\section{Source}

National Cancer Institute. Adjudicator 2. NCI Thesaurus. Code C150868.

An adjudicator performing the assessment that is given the designation of two. 